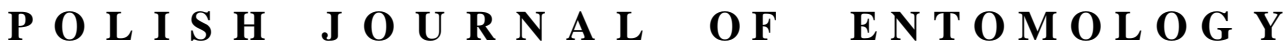

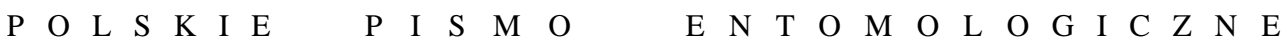

VOL. 84: 163-176

Lublin

30 September 2015

DOI: $10.1515 /$ pjen-2015-0014

\section{The Relationship between Polarized Moonlight and the Number of Pest Microlepidoptera Specimens Caught in Pheromone Traps}

\author{
LÁSZLÓ NOWINSZKY ${ }^{1}$, JÁNOS PUSKÁS ${ }^{1}$, GÁBOR BARCZIKAY ${ }^{2}$ \\ ${ }^{1}$ University of West Hungary, Savaria University Centre, Károlyi G. Square 4, H-9701 \\ Szombathely, Hungary, e-mail: lnowinszky@gmail.com, pjanosgmail.com \\ ${ }^{2}$ County Borsod-Abaúj-Zemplén Agricultural Office of Plant Protection and Soil Conservation \\ Directorate, Vasút Street 22, H-3917 Bodrogkisfalud, Hungary
}

\begin{abstract}
Pheromone traps were deployed in Borsod-Abaúj-Zemplén County (Hungary) between 1982 and 1988, in 1990 and also between 1993 and 2013. These traps attracted 8 Microlepidoptera species: Phyllonorycter blancardella, P. corylifoliella, Anarsia lineatella, Eupoecilia ambiguella, Lobesia botrana, Grapholita funebrana, G. molesta and Cydia pomonella. We examined the trapping data of these species in the context of lunar phases and polarized moonlight. Catches of the European Vine Moth (Lobesia botrana) and the Codling Moth (Cydia pomonella) were higher in the First Quarter, whereas catches of Peach Twig Borer (Anarsia lineatella), Vine Moth (Eupoecilia ambiguella), Plum Fruit Moth (Grapholita funebrana) and Oriental Fruit Moth (Grapholita molesta) were larger in the Last Quarter. Catches of the other two species, the Spotted Tentiform Leafminer (Phyllonorycter blancardella) and Hawthorn Red Midget Moth ( $P$. corylifoliella), were higher in both the First and Last Quarters. When using pheromone traps, insects do not fly to a light source, so moonlight does not modify either the catching distance or flight activity. However, at high levels of polarized moonlight, pheromone trap catches will increase, as in the case of light-trap catches. The results are comprehensible when one considers that the target species can fly both during the daytime and also at night.
\end{abstract}

KEY WORDS: polarized moonlight, lunar phases, pheromone traps, Microlepidoptera.

\section{INTRODUCTION}

Pheromone traps and light traps play an equally important role in pestiferous insect forecasting. However, the efficiency of traps may be influenced by several biotic and 
abiotic factors. As the application of light traps has a history of several decades, scientists have studied the modifying effect of different factors primarily with the aid of such traps. The efficiency of collecting with a light trap is significantly influenced by the Moon. Despite numerous investigations and several interesting results achieved in different parts of the world, opinions on this influence in the international scientific literature are still quite controversial. Although there are several studies in the literature on the efficiency of pheromone traps and the Moon's influence, the details of this relationship remain to be explored. Comprehensive research in this field would be of extreme importance, as the investigation of the Moon's influence on pheromone trap efficiency would also contribute to a better understanding of the relationship between the Moon and light traps. This is because the attracting force of pheromone capsules is not weakened by moonlight. Consequently, any lunar influence detected cannot be explained by the change of collecting distance or the suspected effect of moonlight decreasing flight activity. KEHAT et al. (1975) used traps containing live, intact females and a synthetic pheromone to collect the Cotton Leaf-worm (Spodoptera littoralis BoISDUVAL, 1833) on cotton fields in Israel. No correlation between the catch and lunar phases could be found.

Collecting with synthetic pheromone traps in Malawi, MARKS (1976) found that moonlight had no hindering influence on the collecting of the Pink Bollworm (Pectinophora gossypiella SAUNDERS, 1844). In 1981 and 1982 HO \& REDDY (1983) caught the following moth species on maize and sorghum fields in western Kenya using light traps and pheromone traps baited with intact females: the African White Stem Borer (Maliarpha separatella RAGONOT, 1888), the Spotted Stalk Borer (Chilo partellus SwINHOE, 1885), the African Sugarcane Borer (Eldana saccharina WALKER, 1865), the African Pink Stem Borer (Sesamia calamistis HAMPSON, 1910) and the Maize Stalk Borer (Busseola fusca FULLER, 1901). They found moonlight to have a stronger influence on light trap catches than on pheromone trap catches. HofFMANN et al. (1991) operated a pheromone trap in California to catch Corn Earworms (Heliothis zea BoDDIE, 1850) and Darker-spotted Straw Moths (Heliothis phloxiphaga GROTE et ROBINSON, 1867). Lunation had no influence on the timing of catch peaks. SUCKLING \& BROWN (1992) operated pheromone traps in an orchard in New Zealand between 1989 and 1991 to monitor populations of the Black-lyre Leafroller (Ctenopseustis herana FELDER et ROGENHOFER, 1875), the Green Headed Leafroller (Planotortrix octo DugDALE, 1990), the Codling Moth (Cydia pomonella LinNaEus, 1758) and the Light Brown Apple Moth (Epiphyas postvittana WALKER, 1863): lunation was not found to have any significant influence. In their pheromone trap experiments focusing on the Scarce Bordered Straw (Helicoverpa armigera HÜBNER, 1809), SEKHAR et al. (1995) did not observe any difference between the catch at Full Moon and New Moon. The following studies confirm the theory of decreased trapping efficiency of moths around the time of a Full Moon. To record the weekly number 
of male specimens of the Potato Tubeworm (Phthorimaea operculella ZELLER, 1873), ROUX \& BAUMGARTNER (1995) operated pheromone traps on potato fields in Tunisia between 1986 and 1991. They detected a four-weekly cycle, presumably influenced by the Moon. Operating sex pheromone traps, PARAJULEE et al. (1998) monitored the flight activity of the Corn Earworm (Helicoverpa zea BoDDIE, 1850) and the Tobacco Budworm (Heliothis virescens FABRICIUS, 1777) in Texas for 15 years between 1982 and 1996. The daily catch of the trap was influenced by lunar phases. They revealed a significant positive correlation between the catch and the percentile value of lunar illumination. The maximum daily catch of the trap occurred at Full Moon (71\%), followed by the values of the First Quarter (11\%), Last Quarter (9\%) and New Moon (9\%). Using pheromone traps, RAJARAM et al. (1999) collected cotton pests in 1994 in India. They observed a characteristic difference between the nocturnal activity in the week of the Full Moon and that of the New Moon. The ratio of Full Moon to New Moon weeks was 1:1.40 for the Pink Bollworm (Pectinophora gossypiella SAUNDERS, 1844) and 1:1.17 for the Oriental Leafworm Moth (Spodoptera litura FABRICIUS, 1775). However, DAS \& KATYAR (2001) studied the pheromone trap catch of the Oriental Leafworm Moth (Spodoptera litura) in India. The lowest catch results were recorded at Full Moon. According to their investigations, collecting is more efficient when the Moon is waning than when it is waxing. Between 1973 and 1990 SHENG et al. (2003) operated "Gossyplure" pheromone traps for the Pink Bollworm Moth (Pectinophora gossypiella) at 10 entomological forecast stations in China. The highest activity was recorded in the First Quarter, resulting in a significant catch peak.

We have already studied pheromone trap catch results depending on the phases of the Moon (NOwINSZKY et al. 2010). In this work we publish the distributions of the pheromone trap catch of the target species for each moon phase. We also investigated, using new data, the cause of differences experienced at different moon phases in our present study.

Examining the light-trap catches of the target insect species, we found consistent changes in the catching curves, which seem to show a high correlation with the polarization rate of the moonlight.

The lunar phases are characterized by phase angles, i.e. the angle at the Moon in a SunMoon-Earth triangle. These calculations were carried out by the astronomer György TóTH and were published in our joint PhD thesis (NOwINSZKY \& TóTH 1987).

The methods of spherical astronomy are used to calculate the phase angle. The data we need are the actual coordinates of the Sun, as well as those of the Earth and the Moon; these are published in astronomical year-books, accurate to day, hour and minute. These data can be easily calculated for any date knowing the phase angle values. A lunar month covers 29.53 days and 360 phase angles, an hour includes 12.19 phase angles and a minute 0.203 of a phase angle. The phase angle at Full Moon is $0^{\circ}$, in the Last Quarter $90^{\circ}$, at New Moon $180^{\circ}$ and in the First Quarter $270^{\circ}$. 
Moonlight is linearly polarized. The maximum polarization rate of $7.5 \%$ is reached during \pm 2 days of the First- and the Last Quarter. It is impossible to measure the polarization rate at New Moon \pm 3 days. At Full Moon, the moonlight is not polarized, but during an interval of \pm 2.5 days, the polarization plane is inverted (NOWINSZKY et al. 1979).

The moonlight is partly polarized. The first quantitative measurements were made by LYOT (1929), and later corrected by DOLLFUS (1961). We found only graphical representations in the literature regarding the measurement of polarized moonlight (PELLICORI 1971). The graphical data was digitized by the astronomer György TóTH, who produced a useful context deduced using Fourier analysis (NOWINSZKY \& TÓTH, 1987). LYOT (1929) previously applied a simple correlation to calculate the polarization ratio of $\mathrm{P}=\left(\mathrm{I}_{1}-\mathrm{I}_{2}\right):\left(\mathrm{I}_{1}+\mathrm{I}_{2}\right)$, where $\mathrm{I}_{1}$ is the intensity of the light, the electric vector of which is perpendicular to the plane of the viewing direction, and $\mathrm{I}_{2}$ is the intensity of the light, whose electric vector is parallel. LYOT's (1929) measurements were corrected by DOLLFUS (1961). We deduced the graph (Figure 1) reproduced here from this context (NowINSZKY 2008)

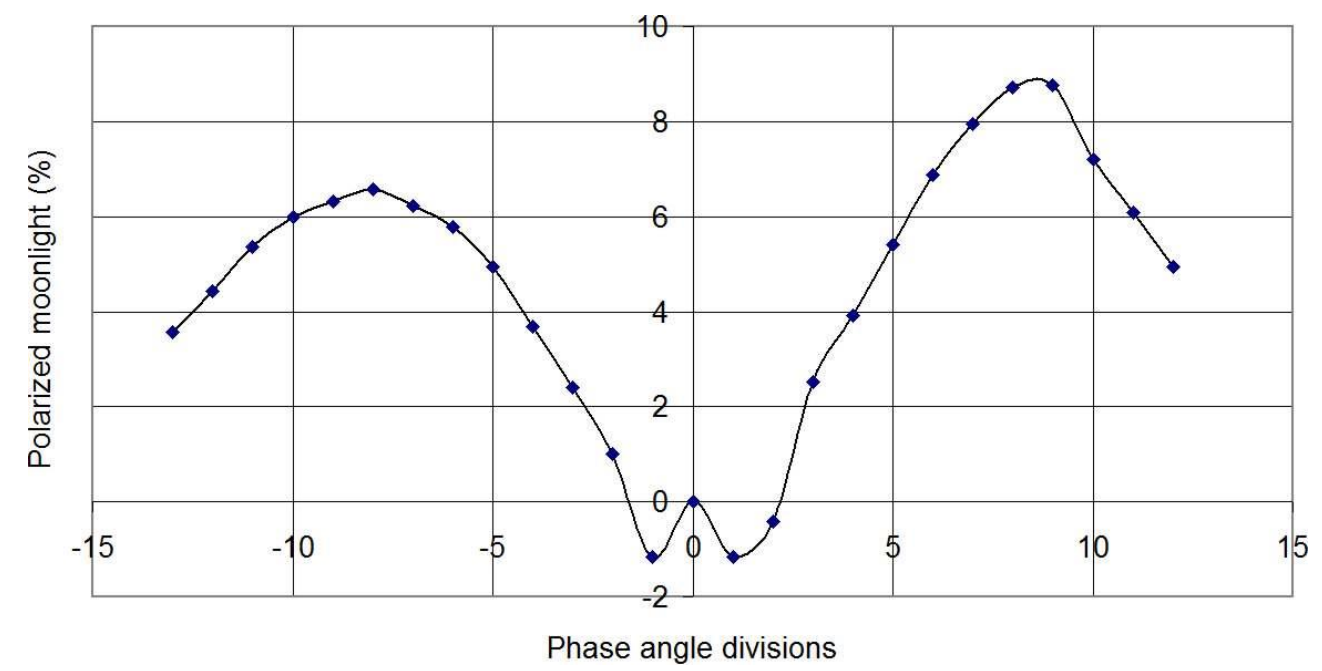

Fig. 1. Polarized moonlight (\%) depending on the phase angle divisions of the Moon.

\section{MATERIALS}

Between 1982 and 1990 pheromone traps were deployed in 9 villages in Borsod-AbaújZemplén County (Hungary-Europe) (Table 1). An additional trap was operated at 
Bodrogkisfalud between 1993 and 2013. These traps attracted a total of 8 Microlepidoptera species: in some years 2-2 pheromone traps were used for each species, whereas in other years not all 8 species were monitored. Catch data of the collected species are displayed in Table 2. We examined the trapping data of these species depending on the Moon's phases.

The traps were operated every day during the season from April until October.

Table 1. Pheromone traps operated in Borsod-Abaúj-Zemplén County.

\begin{tabular}{|l|c|c|}
\hline \multicolumn{1}{|c|}{ Villages } & \multicolumn{2}{c|}{ Geographical coordinates } \\
\hline Bodrogkisfalud & $48: 10.41$ & $21: 21.77$ \\
\hline Bodrogkeresztúr & $48: 09.54$ & $21: 21.64$ \\
\hline Bodrogszegi & 48.26 .82 & $21: 35.61$ \\
\hline Erdőbénye & $48: 15.91$ & $21: 21.18$ \\
\hline Erdőbénye-Meszesmajor & $48: 11.43$ & $21: 22: 46$ \\
\hline Mád & $48: 11.55$ & $21: 16.70$ \\
\hline Sátoraljaújhely & $48: 23.80$ & $21: 39.34$ \\
\hline Tolcsva & $48: 17.05$ & $21: 27.02$ \\
\hline Tokaj & $48: 06.75$ & $21: 24.75$ \\
\hline
\end{tabular}

Table 2. Number and observation data of the target species.

\begin{tabular}{|c|c|c|c|}
\hline \multirow[t]{2}{*}{ Species } & \multirow[t]{2}{*}{ Years } & \multicolumn{2}{|c|}{ Number of } \\
\hline & & Moths & Data \\
\hline $\begin{array}{l}\text { Gracillariidae: Lithocolletinae } \\
\text { Spotted Tentiform Leafminer } \\
\text { Phyllonorycter blancardella FABRICIUS, } 1781\end{array}$ & $1993-2013$ & 95610 & 4023 \\
\hline $\begin{array}{l}\text { Gracillariidae: Lithocolletinae } \\
\text { Hawthorn Red Midget Moth } \\
\text { Phyllonorycter corylifoliella HÜBNER, } 1796\end{array}$ & $2008-2013$ & 10202 & 1712 \\
\hline $\begin{array}{l}\text { Gelechiidae: Anacampsinae } \\
\text { Peach Twig Borer } \\
\text { Anarsia lineatella ZELLER, } 1839\end{array}$ & $1993-2013$ & 14648 & 3552 \\
\hline $\begin{array}{l}\text { Tortricidae: Tortricinae } \\
\text { Vine Moth } \\
\text { Eupoecilia ambiguella HÜBNER, } 1796\end{array}$ & $\begin{array}{c}1987-88,2000, \\
2002\end{array}$ & 2266 & 507 \\
\hline $\begin{array}{l}\text { Tortricidae: Olethreutinae } \\
\text { European Vine Moth } \\
\text { Lobesia botrana DENIS et SCHIFFERMÜLLER, } 1775\end{array}$ & $1987-2013$ & 30270 & 3964 \\
\hline $\begin{array}{l}\text { Tortricidae: Tortricinae } \\
\text { Plum Fruit Moth } \\
\text { Grapholita funebrana Treitschke, } 1846\end{array}$ & $\begin{array}{c}1982-83,1985 \\
1993-2013\end{array}$ & 53386 & 5324 \\
\hline
\end{tabular}


Table 2. Continued.

\begin{tabular}{|l|c|c|c|}
\hline \multicolumn{1}{|c|}{ Species } & Years & \multicolumn{2}{c|}{ Number of } \\
\cline { 3 - 4 } & & Moths & Data \\
\hline Tortricidae: Olethreutinae & 1988, & 26867 & 4375 \\
$\begin{array}{l}\text { Oriental Fruit Moth } \\
\text { Grapholita molesta } \text { BuscK, 1916 }\end{array}$ & $1993-2013$ & & \\
\hline Tortricidae: Olethreutinae & $\begin{array}{c}1982-83,1985, \\
1988,\end{array}$ & 16077 & 3841 \\
$\begin{array}{l}\text { Codling Moth } \\
\text { Cydia pomonella } \text { LINNAEUS, 1758 }\end{array}$ & $1993-2013$ & & \\
\hline
\end{tabular}

\section{METHODS}

We calculated the phase angles for each midnight with a Full Moon. Henceforth, the phase angles were calculated for all the midnights after the Full Moon.

The mean revolution time of the Moon in its orbit around the Earth is 29.53 days. This period is not divisible by whole days, so we used phase angle data. Hourly phase angles change with a value of 12.19. The phase angle division including a Full Moon $\left(0^{\circ}\right.$ or $\left.360^{\circ}\right)$ and values $0 \pm 6^{\circ}$ was designated 0 . Beginning from this group through the First Quarter until a New Moon, divisions were marked as $-1,-2,-3,-4,-5,-6,-7,-8,-9,-10,-11,-12$, 13 and -14 . The next division is \pm 15 , including the New Moon. From the Full Moon through to the Last Quarter in the direction of the New Moon, the divisions were marked as $1,2,3,4,5,6,7,8,9,10,11,12,13$ and 14. Each division consists of 12 degrees (NOWINSZKY 2003, 2008). These phase angle divisions can be related to the four quarters of lunation as follows: Full Moon ( $-2-+2)$, Last Quarter (3-9), New Moon (10 - -10) and First Quarter (-9 - -3). The nights and hours of the periods under examination were all classified in these phase angle divisions.

We calculated the relative catch values of the number of specimens trapped by species and broods. The relative catch (RC) is the ratio of the number of specimens caught in a given sampling unit of time (1 hour or 1 night) to the average number of specimens caught in the same time unit calculated for the whole catch. If the number of specimens trapped equals the average, the value of the relative catch is 1 . Only nights with a catch were included in the calculations, as our earlier works (NOWINSZKY 2003, 2008) had convinced us that although the Moon does influence the efficiency of trapping, it never makes collecting impossible.

The relative catch values were classified by species belonging to the daily phase angle group. The results were plotted. We determined in which Moon Quarter the catch value was significantly higher or lower than the expected value (1). We found higher catch values in the First and Last Quarter periods, when the Moon's light is polarized the most strongly. 
We were looking for the highest correlation between the percentage ratio of polarized moonlight and the relative catch values. We determined the parameters of the curves and the level of significance of the results using the Excel program.

\section{RESULTS}

The results are shown in Figures 2-9.

Catches of the European Vine Moth (Lobesia botrana) and the Codling Moth (Cydia pomonella) were higher in the First Quarter whereas in the Last Quarter catches were higher of the Peach Twig Borer (Anarsia lineatella), Vine Moth (Eupoecilia ambiguella), Plum Fruit Moth (Grapholita funebrana), Oriental Fruit Moth (Grapholita molesta), Spotted Tentiform Leafminer (Phyllonorycter blancardella) and Hawthorn Red Midget Moth (Phyllonorycter corylifoliella). The flight intensity of all 8 species can be described using increasing curves: if the polarized moonlight was stronger, the relative catch increased. Only two species (Grapholita funebrana, Grapholita molesta) initially exhibited a decreasing section, but after the minimum value there followed a significant increase in the curves.

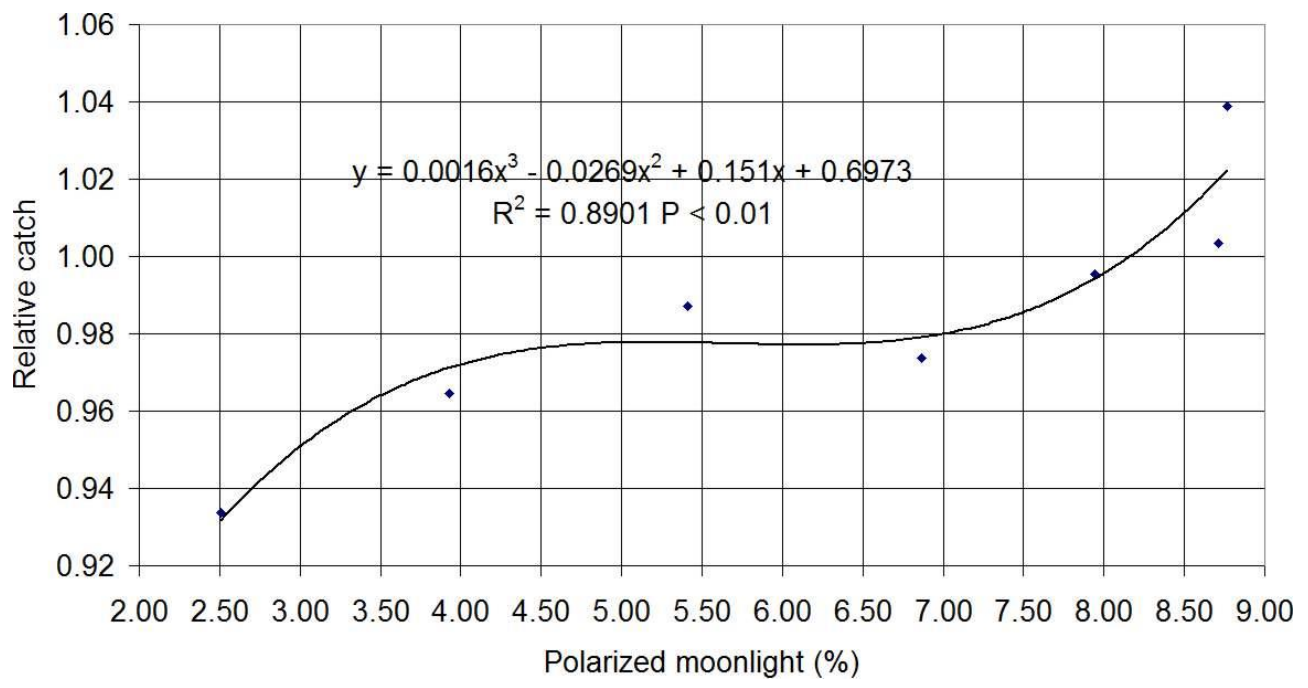

Fig. 2. Pheromone trap catch of the Spotted Tentiform Leafminer (Phyllonorycter blancardella) as a function of polarized moonlinght (Last Quarter). 


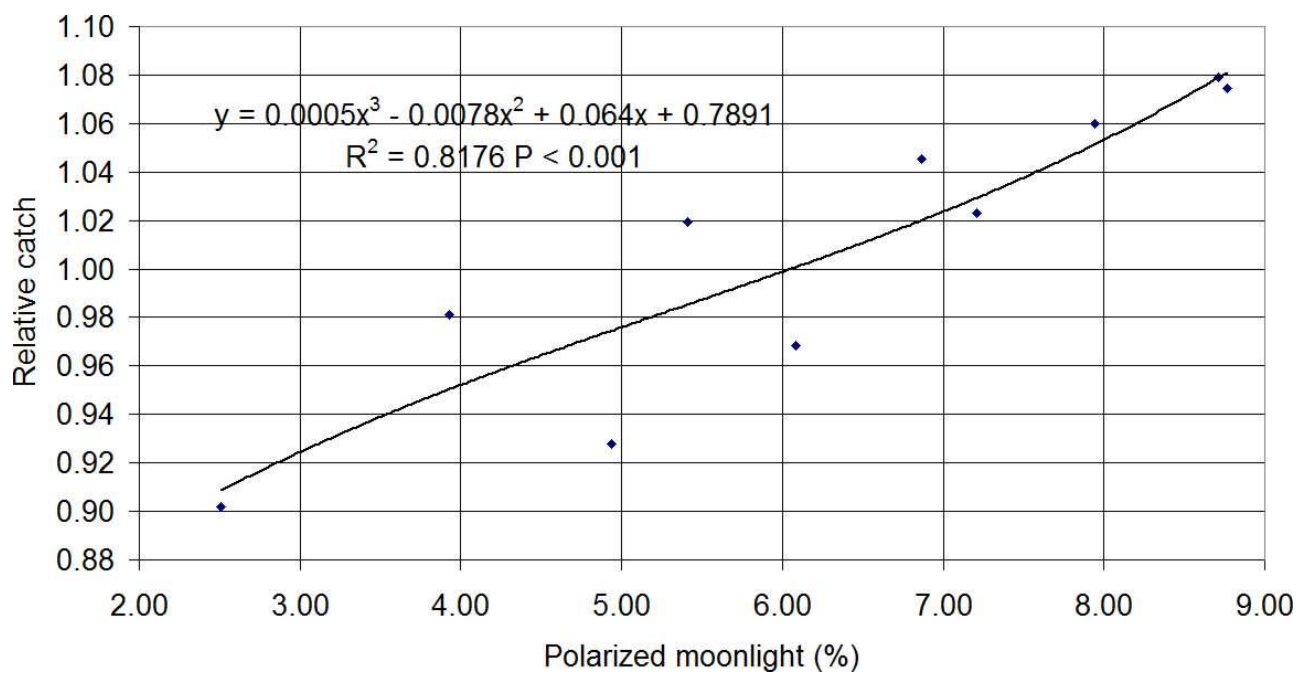

Fig. 3. Pheromone trap catch of the Red Midget Moth (Phyllonorycter blancardella) as a function of polarized moonlinght (Last Quarter).

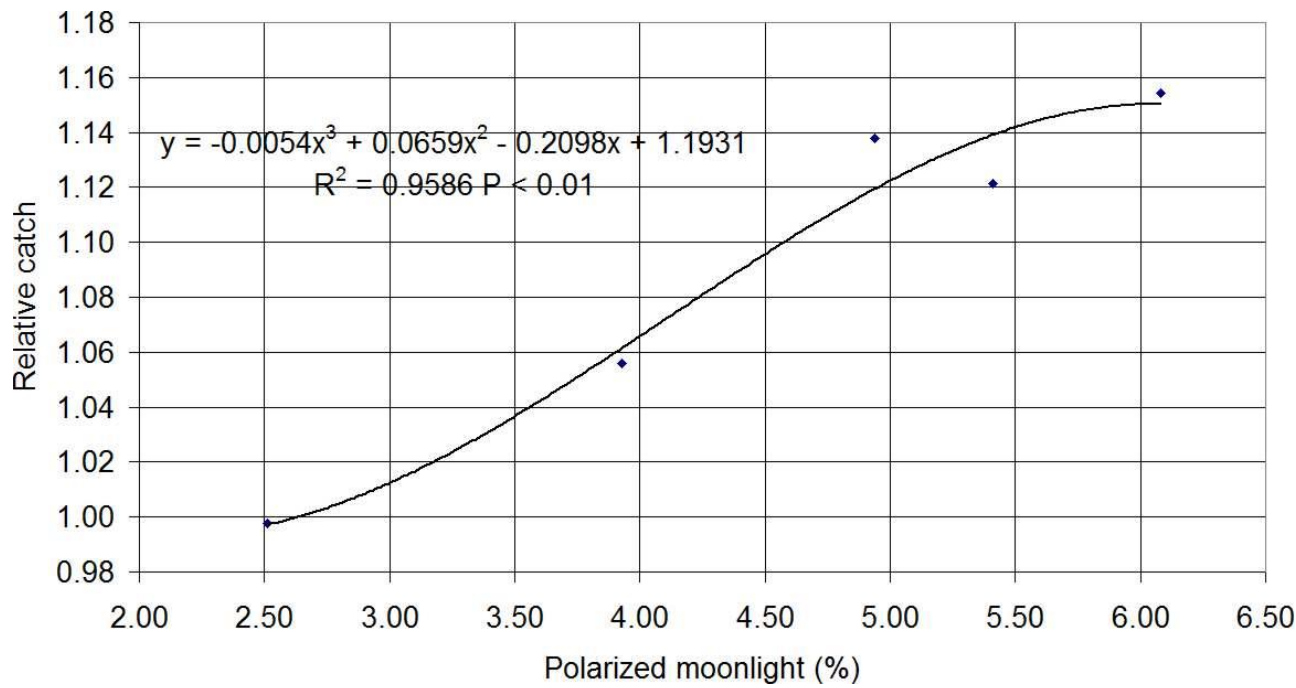

Fig. 4. Pheromone trap catch of the Peach Twig Borer (Anarsia lineatella) as a function of polarized moonlinght (Last Quarter). 


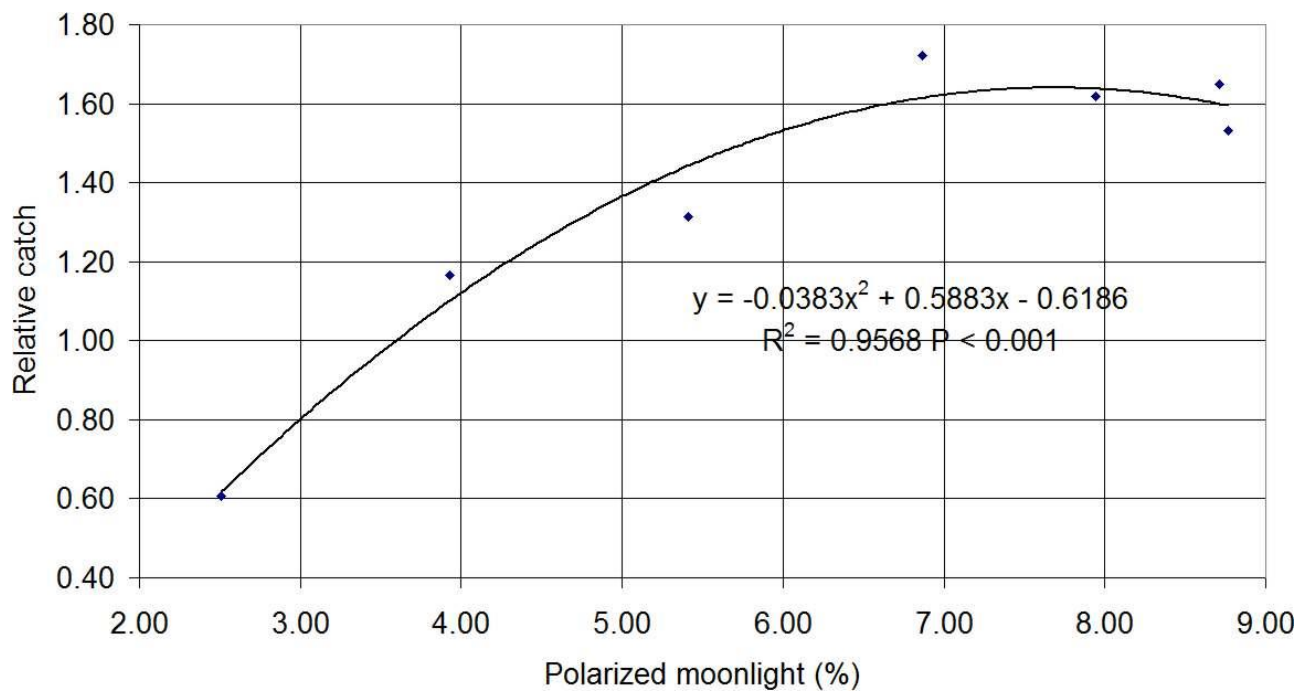

Fig. 5. Pheromone trap catch of the Vine Moth (Eupoecilia ambiguella) as a function of polarized moonlinght (Last Quarter).

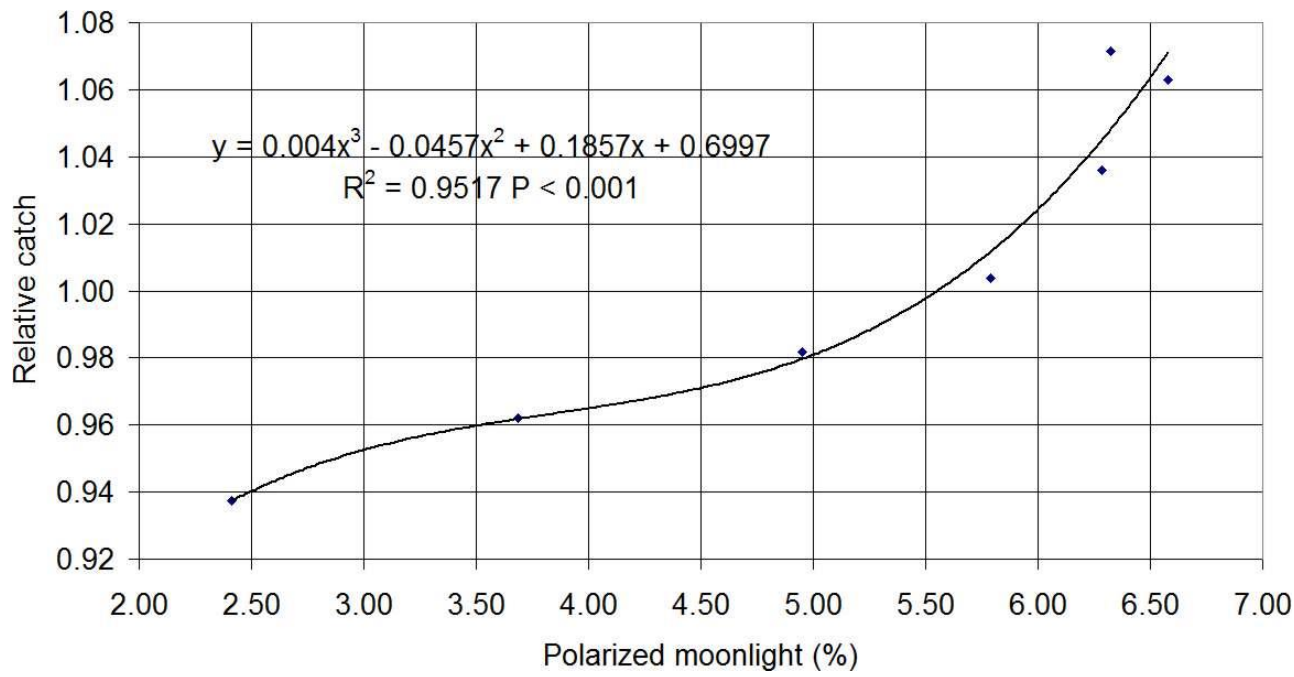

Fig. 6. Pheromone trap catch of the European Vine Moth (Lobesia botrana) as a function of polarized moonlinght (First Quarter). 


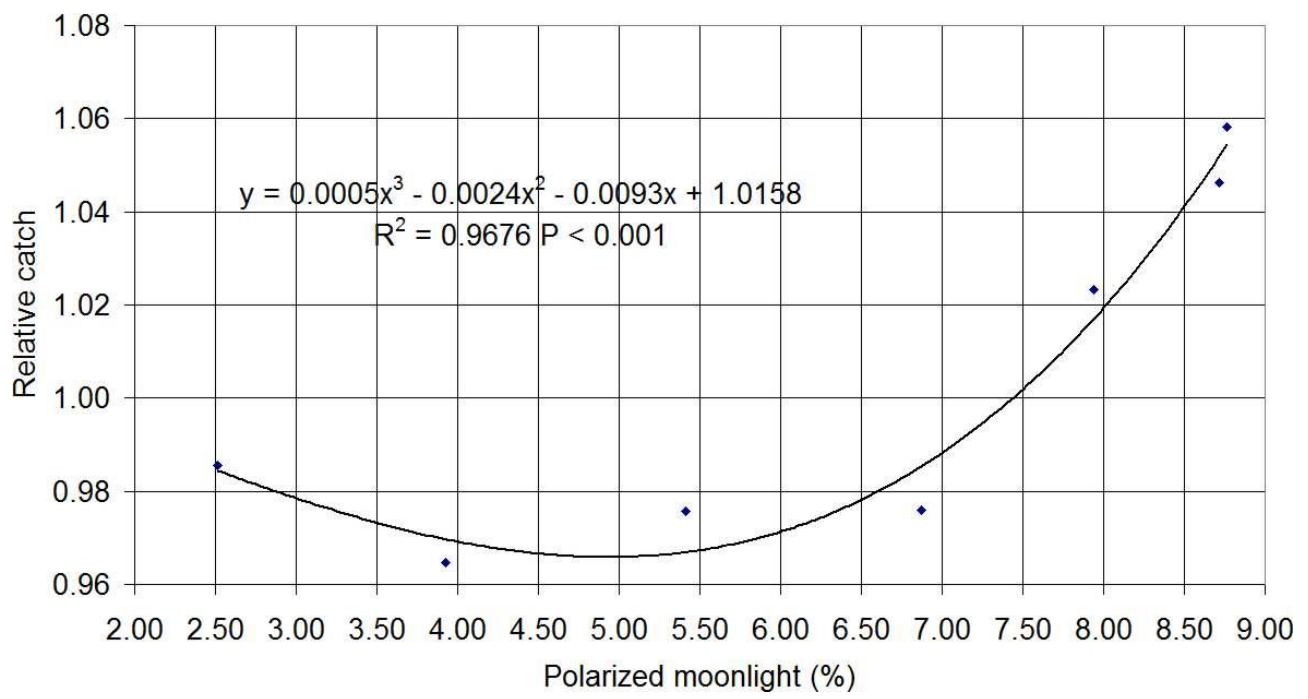

Fig. 7. Pheromone trap catch of the Plum Fruit Moth (Grapholita funebrana) as a function of polarized moonlinght (Last Quarter).

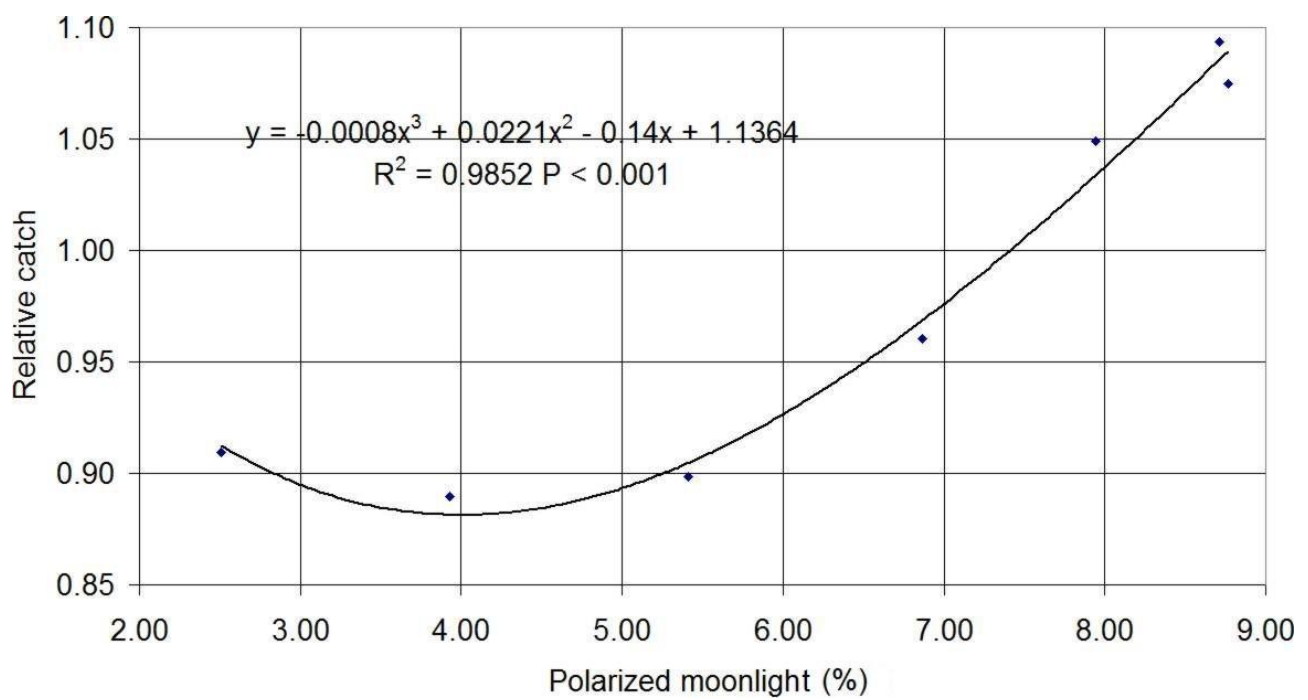

Fig. 8. Pheromone trap catch of the Oriental Fruit Moth (Grapholita molesta) as a function of polarized moonlinght (Last Quarter). 


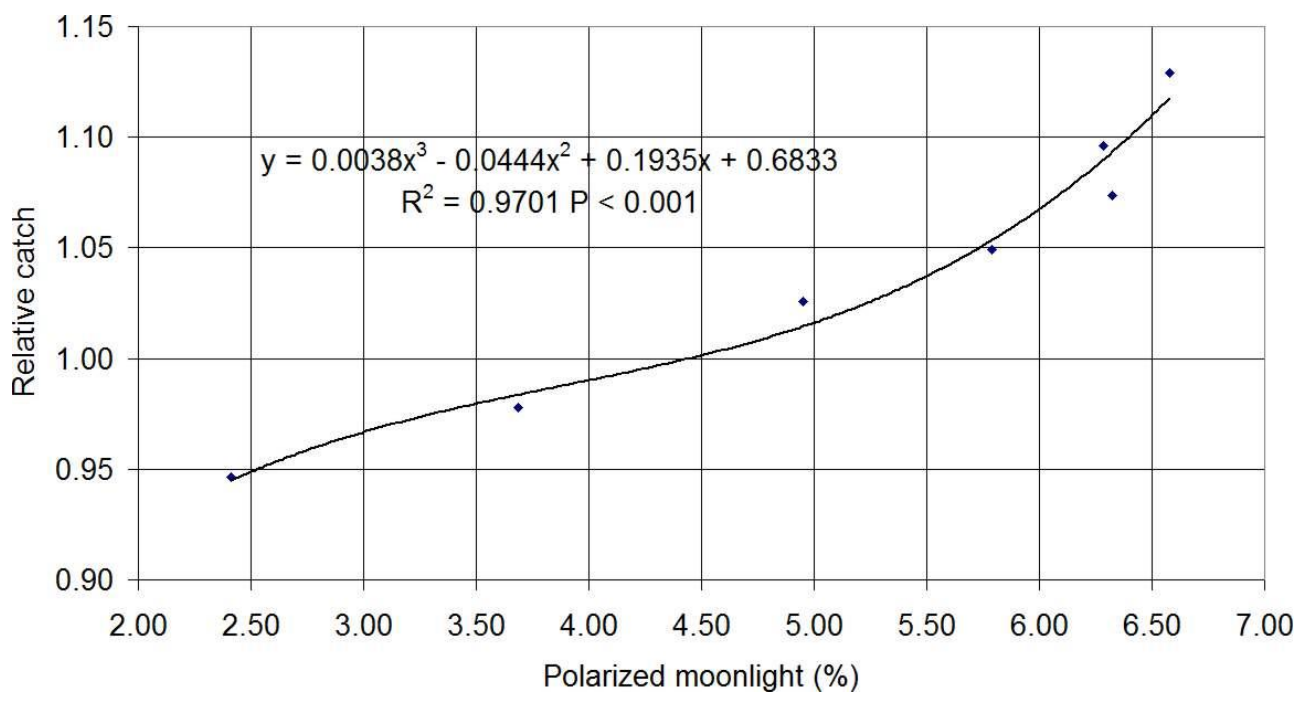

Fig. 9. Pheromone trap catch of the Codling Moth (Cydia pomonella) as a function of polarized moonlinght (First Quarter).

\section{DISCUSSION}

Specimens of all the 8 species examined can be collected in various numbers on the different days of the lunar phase. Consequently, the Moon has an influence on the efficiency of the trapping of these species. However, this influence cannot solely be attributed to moonlight. In the case of light trap studies, the majority of scientists share the view of WiLLIAMS (1936), ascribing catch divergences during lunation to the smaller collecting distances caused by moonlight or reduced flight activity, perhaps to the behaviour of the moths flying in higher layers of air (EL-ZIADY 1957). Nevertheless, in the case of pheromone traps insects do not fly to a light source, so moonlight may not have a similar influence on this method of trapping. Based on our results, we presume the life cycles of the Microlepidoptera species examined to be somehow related to lunation. The life of moths is usually short, so there should be some kind of timing factor ensuring that mature specimens find each other. The regularly changing lunar phases seem to be appropriate for this purpose (NOWINSZKY \& PUSKÁS 2013).

Further research would be necessary to acquire more comprehensive knowledge of lunar influence also in the case of pheromone traps. The recognition that lunar influence is not identical with the influence of moonlight is an important new result of our work. Similar investigations based on data from traps baited with intact females could be interesting. Through these studies we could get an answer to the question of whether the 
pheromone emission of females is independent of the lunar phases.

The reason for this may be that Lobesiana botrana and Cydia pomonella are the most abundant moths flying at dusk (NAGY 1993, REICHART 1993). The Moon can be seen above the horizon in the evening at First Quarter. Unlike all the other species that are maximum caught in the Last Quarter. However, according to our observations, these species fly en masse after midnight and the Moon in this moon phase stays above the horizon.

The relative catch is high in the First Quarter and Last Quarter because the polarized moonlight is then reaches its maximum level. A third-degree polynomial can be seen in the Figures, except Figure 5, which is a second-degree polynomial.

The moonlight does not modify the catching distance and, hence, does not affect flight activity either.

In pheromone trapping the bait is light, so the collecting area, modified by the moonlight, has no influence on the quantity of the catch. We did not find any relationship with the strength of the moonlight. However, we did find a very impressive and highly significant relationship with polarized moonlight.

We could not find any influence of the moon on species during the full lunar month. It is not surprising that the difference between the lowest and highest catch in the lunar month was much lower than we experienced with light trap catches. The explanation may be that the target species fly by day and also at night, although not at the same intensity during the whole 24 hours. Most moths fly to pheromone capsules at dusk and dawn; some are caught at night, but very few during the day.

\section{REFERENCES}

DAS S.B., KATYAR N.P. 2001. Effect of moon light and lunar periodicity on the pheromone trap catches of tobacco caterpillar (Spodoptera litura FAB.) moths. Crop Research 21(2): 229-236.

Dollfus A. 1961. Polarization studies of planets. [in:] G.P. KuIPER, B.M. MidDlehurst (eds.). The solar system 3. Planets and satelites. University of Chicago Press, Chicago.

EL-ZIADY S. 1957. A probable effect of the moonlight on the vertical distribution of Diptera. Bulletin de la Société entomologique d'Égypte 41: 655-662.

Ho D.T., REDDY K.V.S. 1983. Monitoring of lepidopterous stem-borer population by pheromone and light traps. International Journal of Tropical Insect Science 4(1-2): 19-23.

HofFMANN M.P., WiLSON L.T., ZALOM F.G. 1991. Area-wide pheromone trapping of Helicoverpa zea and Heliothis phloxiphaga (Lepidoptera: Noctuidae) in the Sacramento and San Joaquin Valleys of California. Journal of Economic Entomology 84(3): 902-911.

Kehat M., Genizi A., Greenberg S. 1975. The use of traps baited with live females or synthetic pheromone as a tool for improving control programs of the cotton leaf-worm, Spodoptera littoralis (BOISD.), in cotton fields in Israel. Phytoparasitica 3(1): 3-18. 
Lуот B. 1929. Rechearches sur le polarisation de la lumiére des planets et quelques substances terrestres. Annales de l'Observatoire de Paris, Section de Meudon 8(1): 1-160.

MARKS R.J. 1976. Field evaluation of gossyplure, the synthetic sex pheromone of Pink Bollworm Pectinophora gossypiella (SAUND.) (Lepidoptera, Gelechiidae) in Malawi. Bulletin of Entomological Research 66(2): 267-278.

NAGY B. 1993. Codling Moth (Cydia pomonella LinnÉ). [in:] T. JeRmY, K. BALÁzs (eds.) Guide to the zoology of pestst. Vol. 4A. Akadémia Kiadó, Budapest, 384-415. (in Hungarian)

NowINSZKY L. 2003. The Handbook of Light Trapping. Savaria University Press, Szombathely.

NOwINSZKY L. 2008. Light Trapping and the Moon. Savaria University Press, Szombathely.

NowinsZKy L., BARCZIKAy G., PUSKÁs J. 2010. The relationship between lunar phases and the number of pest Microlepidoptera specimens caught by pheromone traps. Asian Journal of Experimental Biological Sciences, 1(1): 14-19.

NOwINSZKY L., PUSKÁs J. 2013. Light-trap catch of harmful Microlepidoptera species in connection with polarized moonlight and collecting distance. Journal of Advanced Laboratory Research in Biology 4(4): 108-117.

NowinszKy L., Szabó S., Tóth G, EкK I., KISS M. 1979. The effect of the moon phases and of the intensity of polarized moonlight on the light-trap catches. Zeitschrift für Angewandte Entomologie 88(1-5): 337-355.

NowinsZKY L., Tо́тн Gy. 1987. Influence of cosmic factors on the light-trap catches of harmful insects. Ph.D. Dissertation, University of West Hungaria, Szombathely. (in Hungarian)

PaRAJUleE M.N., Slosser J.E., Boring E.P. 1998. Seasonal activity of Helicoverpa zea and Heliothis virescens (Lepidoptera: Noctuidae) detected by pheromone traps in the rolling plains of Texas. Environmental Entomology 27(5): 1203-1219.

PELLICORI S.F. 1971. Polarizing properties of pulverized materials with special reference to the lunar surface. Applied Optics 10(2): 270-285.

RAJARAM V., JANARTHANAN R., RAMAMURTHY R. 1999. Influence of weather parameters and moon light on the attraction of light trap and pheromone trap catches of cotton pests under dry farming system. Annals of Agricultural Research 20(3): 282-285.

ReICHART G. 1993. European Vine Moth (Lobesia bortana Denis et SCHIFFermüLler). [in:] T. JERMY, K. BALÁzs (eds.). Guide to the zoology of pestst. Vol. 4A. Akadémia Kiadó, Budapest, 291-300. (in Hungarian)

Roux O., Baumgartner J. 1995. Potato-tuber moth Phthorimaea operculella (Zeller) (Lep., Gelechiidae) and tuber infestation in Tunisian potato fields - analysis of the flight phenology. Journal of Applied Entomology 119(5): 315-319.

Sekhar P.R., Venkataiah M., Venugopal Rao N. 1995. Effect of moon light and lunar periodicity on the pheromone trap catches of Helicoverpa armigera (HUBNER) moths. Annals of Agricultural Research 17(1): 53-55.

SHENG C.F., WANG H.T., WANG S.L., XUAN W.J. 2003. A discussion on the relation between moon phase and moth peak day using Gossyplure. China Cotton 30(2): 13-14.

SuCKLING D.M., Brown B. 1992. Daily performance of orchard pheromone traps. Proceedings of the New Zealand Plant Protection Conference 45: 279-284. 
WiLLiams C.B. 1936. The influence of moonlight on the activity of certain nocturnal insects, particularly of the family of Noctuidae as indicated by light-trap. Philosophical Transactions of the Royal Society of London. Series B 226(537): 357-389.

Received: 15 June 2015

Accepted: 31 July 2015 